ECOLOGICA, Vol. 28, No 103 (2021), 417-425

https://doi.org/10.18485/ecologica.2021.28.103.12

Originalni naučni rad

UDC: 338.48-6:502/504]:[616.98:578.834](497.11)

\title{
Ekoturizam u uslovima pandemije COVID-19 na primeru Donjeg Podunavlja
}

\section{Ecotourism in conditions of pandemic COVID-19 on the example of the Lower Danube Region}

\author{
Ivana Vasić1, Nikica Radović2* \\ 1,2Univerzitet Singidunum, Danijelova 32, Beograd, Srbija / \\ Singidunum University, Danijelova 32, Belgrade, Serbia \\ *Autor za prepisku / Corresponding author
}

Rad primljen / Received: 08.12.2020, Rad prihvaćen / Accepted: 05.08.2021.

\begin{abstract}
Sažetak: Turizam je u proteklih nekoliko decenija imao izuzetno povoljnu tendenciju rasta, iako se neprekidno suočavao sa krizama koje su uticale na njegov razvoj. Od početka XXI veka, turistička delatnost je bila pod uticajem nekoliko značajnih kriza koje su prouzrokovale pad turističkog prometa i prihoda na svetskom turističkom tržištu. Najveći negativni efekti ostvareni su pod uticaje zdravstvene krize izazvane prisustvom virusa SARS-CoV-2, opšte prihvaćenim kao COVID-19. Pandemija COVID-19 može se posmatrati kao zdravstvena, ekološka, ekonomska i socijalna kriza i direktno je povezana sa razvojem održivog turizma i pitanjima zaštite životne sredine. Posle više od godinu dana pandemije koja je uticala na sve aspekte našeg života, nameće se pitanje kako će izgledati putovanja u narednom periodu? Cilj ovog rada jeste da se definišu, odnosno identifikuju društveno-ekonomske posledice izazvane prisustvom virusa SARS-CoV-2 sa posebnim osvrtom na razvoj i ekspanziju ekoturizma, tj. da li ekoturizam kao paradigma održivog razvoja može spasiti turizam u post-COVID eri?
\end{abstract}

Ključne reči: ekoturizam, virus SARS-CoV-2, pandemija COVID-19, ekonomska kriza, održivi razvoj.

\begin{abstract}
Tourism has had an extremely favorable growth trend in the past few decades, although it has constantly faced crises that have affected its development. Since the beginning of the 21 st century, tourism has been affected by several significant crises that have caused a decline in tourism turnover and revenue in the global tourism market. The greatest negative effects were achieved under the influence of the health crisis caused by the presence of the SARS-CoV-2 virus, generally accepted as COVID-19. The COVID-19 pandemic can be seen as a health, environmental, economic and social crisis and is directly related to the development of sustainable tourism and environmental issues. After more than a year of a pandemic that has affected all aspects of our lives, the question arises as to what travel will look like in the coming period? The aim of this paper is to define, ie identify the socio-economic consequences caused by the presence of the SARS-CoV-2 virus with special reference to the development and expansion of ecotourism, ie. can ecotourism as a paradigm of sustainable development save tourism in the post-COVID era?
\end{abstract}

Keywords: ecotourism, SARS-CoV-2 virus, COVID-19 pandemic, economic crisis, sustainable development.

${ }^{1}$ orcid.org/0000-0002-3309-3472, email: ivasic@singidunum.ac.rs

2orcid.org/0000-0001-5415-6746, email: nradovic@singidunum.ac.rs 


\section{UVOD / INTRODUCTION}

Tokom proteklih decenija, industrija turizma doživela je kontinuiranu ekspanziju i diverzifikaciju i postala jedna od najvećih i najbrže rastućih privrednih delatnosti na svetu, a prema podacima UNWTO u 2019. godini bila je na trećem mestu sa ostvarenih 2,194 milijardi američkih dolara posle naftne i hemijske industrije, a ispred automobilske industrije (UNWTO, 2021). Razvojni put turizma može se podeliti na dve epohe: epohu turizma privilegovanih klasa i epohu savremenog turizma (Unković, Zečević, 2016). Epoha savremenog turizma najznačajnija je etapa od završetka II svetskog rata čija osobenost jeste uključivanje širokih masa stanovništva u turistička putovanja. Razvoj železničkog, drumskog i vazdušnog saobraćaja, skraćenje radnog vremena i uvođenje plaćenih godišnjih odmora, podizanje opšteobrazovnog nivoa stanovništva, pojava novih savremenih oblika organizacije turističkih putovanja, kao i primena informacionih tehnologija uticali su da turizam poprimi masovni karakter. Vremenom, masovni turizam počinje drastično da utiče na degradaciju životne sredine što 80 -tih godina prošlog veka uslovljava pojavu ekoturizma. Ekoturizam nastaje kao odgovor na prouzrokovane, loše učinke masovnog turizma i označava potrebu za doživljajem netaknute prirode. Jednu od prvih definicija ekoturizma dalo je Međunarodno udruženje za ekoturizam (TIES) koja glasi: „Ekoturizam je odgovorno poslovanje u oblasti prirode, kojim se čuva životna sredina i poboljš̌ava dobrobit lokalnog stanovništva" (Wood Epler, 2002).

\section{MATERIJALI I METODE / \\ MATERIALS AND METHODS}

U ovom radu obrađen je uticaj pandemije COVID 19 na industriju turizma, sa osvrtom na specifičnosti ekoturizma kao i njegovog uticaja na oporavak industrije turizma i porast u broju kretanja turista. $\mathrm{S}$ tim u vezi formirane su određene hipoteze:

H1: Pandemija COVID-19 uticala je na sve aspekte života savremenog čoveka izazivajući uvođenje određenih mera koje su neprikladne za normalnu realizaciju ekonomskih i društvenih procesa izazivajući destabilizaciju mnogih država u svetu

H2: Ekoturizam kao paradigma održivog razvoja ima potencijala da "regeneriše" turizam u postCOVID eri

Primenom "desk research" metode, metode komparacije, proučavanjem naučnih radova, knjiga i sajtova cilj rada je je da se približi problem valorizacije ekoturizma, kao i da se. potvrde ili opovrgnu postavljene hipoteze. Implementacijom studije slučaja valorizacije ekoturizma na prostoru destinacije Donjeg Podunavlja jedan od ciljeva rada je da se ukaže na potencijale prostora destinacije Srbije za dalji razvoj, kao i investicije u inovacije u ekoturizam, koji je sa globalnog aspekta održivi i brzo rastući oblik turizma.

\section{REZULTATI I DISKUSIJA / RESULTS AND DISCUSSION}

\section{Pojam ekoturizma i razvoj tokom vremena}

Pojam zaštite životne sredine i prirodnih resursa poznat je od samog nastanka ljudskih civilizacija. Narodi uslovljeni kulturološkim i tradicionalnim razlikama na različite načine su poimali termine vezane za značaj i očuvanje prirodnih područja kroz istoriju. Asirski vladari su 8 vekova pre nove ere osnovali rezervate za lov i jahanje, dok su se afrička plemena bavila zaštitom biljnih vrsta koje su korišćene u religiozne svrhe. Zaštita većih područja počinje početkom XI veka u Velikoj Britaniji, a glavni cilj je bio da za vlastelu budu formirana individualna/sopstvena lovišta, bez pristupa lokalnog stanovništva. Prvi nacionalni park u Evropi osnovan je 1909. godine - Nacionalni park Abisko u Švedskoj (Marković, 2019). Nakon II svetskog rata, tačnije 1946. godine osnovana je Međunarodna unija za zaštitu prirode (International Union for Conservation of Nature - IUCN), najveća globalna organizacija za zaštitu životne sredine koja broji više od 1400 članica, iz preko 160 zemalja sveta. Analiza globalne situacije pomogla je u vođenju pripreme IUCN programa 2017-2020. Program se razlikuje od nekada raširene zablude da se globalni izazovi moraju rešavati odvojeno, i umesto toga prepoznaje da ekološka, ekonomska, pa čak i politička zabrinutost često dele direktne i indirektne pokretače i da na sličan način mogu imati koristi od zajedničkih rešenja. Program takođe odražava uverenje IUCN-a da se stalan porast globalnog blagostanja može postići samo boljim razumevanjem složenih sistema za održavanje života na planeti i dominantnih globalnih trendova koji trenutno deluju na njih - urbanizacija, ekonomski rast, rastuća potrošnja, nestajanje biodiverziteta, nejednakost bogatstva, klimatske promene, rast stanovništva i mnogi drugi (IUCN, 2016).

UNWTO održivi turizam definiše kao turizam koji u potpunosti poštuje svoje sadašnje i buduće ekonomske, društvene i ekološke uticaje, istovremeno obezbeđujući potrebe posetilaca turizma kao privredne delatnosti i lokalnih zajednica uz očuvanje prirodne sredine (UNWTO, 2005). Ekoturizam je prema Epler Wood (2002) definisan kroz svoje rezultate u održivom razvoju, kroz zaštitu oblasti prirode, stvaranje koristi za lokalno stanovništvo, kao i za obrazovanje posetilaca o održivosti. Dakle, održivi turizam predstavlja koncept koji je potrebno implementirati u sve vidove turizma, dok ekoturizam predstavlja specifičan, selektivni vid turizma koji počiva na primeni održivog razvoja. lako su slični 
pojmovi, valja napraviti razliku između održivog i ekoturizma. Prema Bradić-Martinović i Miletić (2018) "ekoturizam je više fokusiran na ekološku zaštitu i obrazovanje gostiju o lokalnom, prirodnom okruženju, dok je održivi turizam fokusiran na putovanja koja imaju najmanji mogući negativni uticaj na okruženje i lokalne zajednice". Za ekoturizam se kaže da je paradigma održivog razvoja (Marković, 2019).

Prema Međunarodnom udruženju za ekoturizam cilj razvoja ekoturizma je objedinjavanje zaštite, zajednica i održivog putovanja. Dakle, subjekti koji sprovode, učestvuju u aktivnostima ekološkog turizma i plasiraju in na tržište trebalo bi da implemetiraju sledeće principe ekoturizma u svojim poslovnim procesima:

- $\quad$ minimiziranje fizičkih, socijalnih i psiholoških uticaja
- $\quad$ izgradnja ekološke i kulturne svesti i poštovanja

- $\quad$ prezentovanje pozitivnih iskustava i posetiocima i domaćinima

- $\quad$ obezbeđenje direktne finansijske koristi za očuvanje resursa i prostora

- osmisliti finansijske koristi kako za lokalno stanovništvo, tako i za investitore

- posetiocima pružiti nezaboravna interpretativna iskustva koja pomažu u podizanju osetljivosti na političku, ekološku i društvenu klimu zemalja domaćina

- $\quad$ prepoznavanje prava, kulture i tradicionalnih vrednosti naroda domaćina i razvijati partnerstva sa njima u cilju osnaživanja.

Lindberg (1991) je formirao tipologiju nekoliko vrsta ekoturizma:

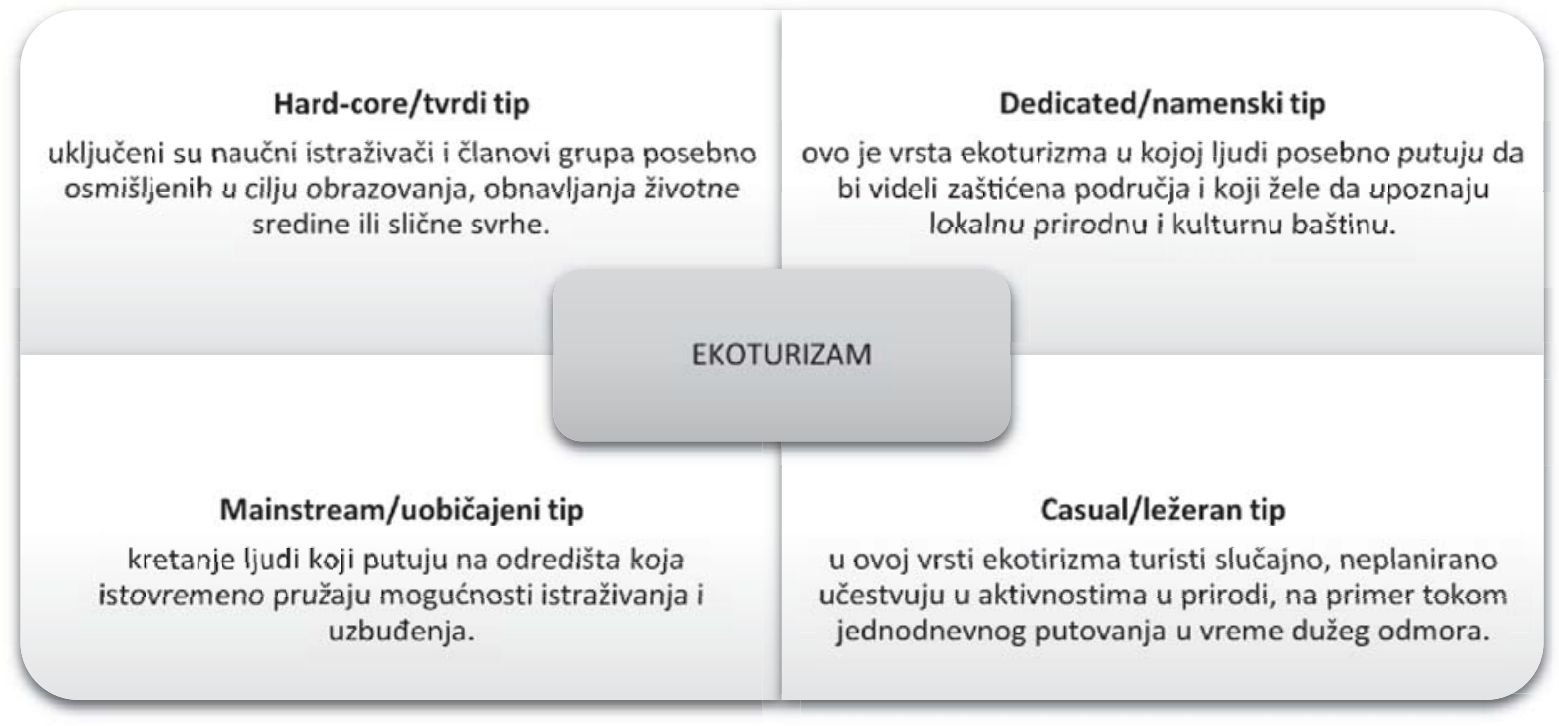

Slika 1 - Tipologija ekoturizma / Figure 1 - Typology of ecotourism Izvor / Source: autori prilagodili prema Lindberg, 1991.

U skladu sa navedenim vrstama ekoturizma, a s obzirom na raznorodne aktivnosti putnika, ključno razmatranje je raznolikost na tržištu ekoturizma. Prema FAO eko-turiste diferenciramo sa nekoliko aspekata, uključujući: pređenu razdaljina putovanja, dužinu boravka, željeni nivo fizičkog napora i udobnosti, značaj prirode u motivaciji za putovanje, željeni nivo učenja, iznos potrošnje, željene aktivnosti i lične demografske kategorije (www.fao.org). Imajući u vidu promene potreba savremenih turista sve je zastupljeniji stav da je ekoturizam vrsta turizma koja je u usponu, a što se u 2020. godini potvrdilo. Prema podacima portala Statista.com (2021, slika 2) industrija ekoturizma širom sveta procenjena je na 181,1 milijardu američkih dolara u 2019. Prognoze su da će sektor dostići 333,8 milijardi američkih dolara u 2027. godini.

Prema principima na kojima počiva, ekoturizam implementiran kroz prizmu održivog razvoja, prema Janković et al. (2020) predstavlja koncept koji je osnova jednog od glavnih pokreta u okviru globalnih klimatskih izazova i milenijumskih razvojnih ciljeva. U svetu su, zahvaljujući bogatstvu i specifičnosti prirodnih dobara pojedine države prepoznate kao ekodestinacije (Australija, Andora, Kostarika, Peru), pa ova vrsta turizma u okviru njihovog prostora ima dominantnu zastupljenost i generiše najveći udeo prihoda po osnovu turističkih kretanja. Na mnogo načina se potvrdilo da je ekoturizam „mikrokosmos“ svih pitanja održivog turizma, ali i da se više nego 
održivi turizam fokusira na specifične teme osobenih ekosistema i tradicionalnih kultura (Dražić, 2018). Zahvaljujući mnogobrojnim prirodnim dobrima koja su rasprostranjena na prostoru Srbije postoje veliki potencijali za unapređenje ekoturizma u okviru turističke ponude naše zemlje, kao atraktivan vid ponude na globalnom turističkom tržištu.

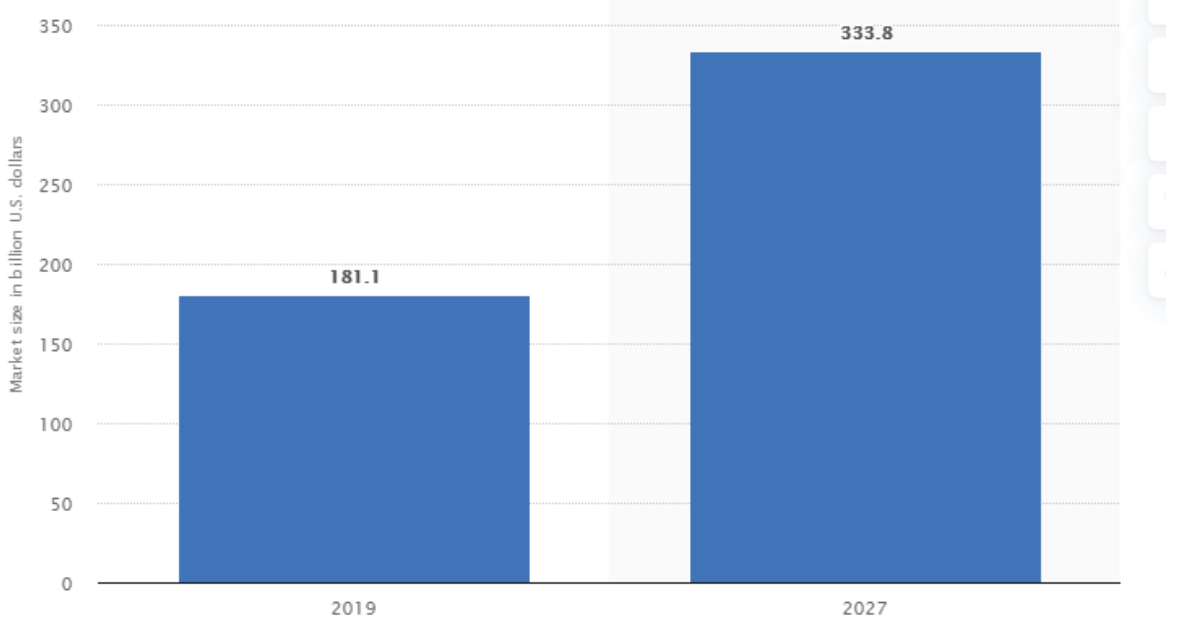

(C) Statista 2021

Slika 2 - Globalno tržišno učešće ekoturizma u 2019. godini, sa prognozom za 2027. godinu (u milijardama američkih dolara)

Figure 2 - Global market share of eco-tourism in 2019, with a forecast for the year 2027 (in billions of US dollars)

Izvor / Source: www.statista.com

Savremena kretanja i uticaj pandemije COVID-19 na ekoturizam

Čovečanstvo se od svog nastanka suočava sa velikim brojem kriza - ekonomskim, socijalnim, prirodnim, političkim, terorističkim ili pak zdravstvenim. Cena razvoja i napretka ljudskih civilizacija, oslonjena je na razvoj i primenu tehnologija, intenzivnu upotrebu neobnovljivih izvora energije, koje sa sobom nose niz negativnih posledica koje ugrožavaju opstanak budućih generacija. Početak 19. veka obeležila je industrijska revolucija koja je ujedno značila i kraj održivog življenja, prouzrokujući niz negativnih faktora, a pod uticajem ljudi, kao ključnih izazivača. Zagađenje vode, zemljišta, vazduha, globalno zagrevanje i oštećenje ozonskog omotača, izumiranje autohtonih biljnih i životinjskih vrsta, pojava novih bolesti, samo su deo posledica sa kojima se ljudska civilizacija suočava poslednjih decenija. Narušavanje biodiverziteta, odnosno degradacija životne sredine u uskoj je povezanosti sa našim zdravljem i kvalitetom života u savremenom svetu. Pojava novog virusa SARS-CoV-2 krajem 2019. godine, izazivača pandemije COVID-19, predstavlja jednu od najvećih globalnih pretnji čovečanstvu zadnjih decenija i stoleća, sa više aspekata.

Zdravstvene krize i njihov uticaj na globalni razvoj turizma, neophodno je sagledati sa različitih aspe- kata, odnosno potrebna su istraživanja iz različitih oblasti. Najveće probleme koje svaka zdravstvena kriza nosi sa sobom, pa i pandemija COVID-19, odnosi se na zdravlje i ugroženu bezbednost ljudi širom planete. Poslednje dve decenije bilo je nekoliko ozbiljnih pandemija koje su uticale na turističke tokove, prouzrokujući krize, kao što su: ptičiji grip, grip H1N1, SARS i ebola, a sada i pojava najnovije pandemije COVID-19.

Janković et al. (2021) navode da ekonomska situacija ostaje globalno vrlo fluidna za većinu zemalja i regiona, uz neizvesnost oko dužine i dubine negativnih ekonomskih efekata povezanih sa zdravstvenom krizom što izaziva nestabilnosti na finansijskim tržištima i teškoće u donošenju korporativnih odluka, ali i nesigurnost u pogledu razvoja i dužine globalne pandemije i efikasnosti javnih politika čiji je cilj da spreče njeno širenje i naredne talase povećale su nestabilnost tržišta. Prema Đurović et al. (2020) pandemija COVID-19 prouzrokovala je dalekosežne posledice na globalnu ekonomiju zbog bliske povezanosti sa drugim sektorima uključujući obrazovanje, nekretnine, sport i turizam.

U 2020. godini došlo je do brojnih ekonomskih blokada i ograničenja, uz velika socijalna distanciranja, te je ova godina proglašena za, do sada, prema globalnim rezultatima, najlošiju godinu za 
industriju turizma. Život sa novim virusom, tačnije „nova normalnost“ nameću pitanje kako će izgledati putovanja u budućnosti i da li postoji vid turizma koji je atraktivan i odgovarajući u ovim specifičnim uslovima? Pored brojnih ekonomskih, socijalnih uticaja, blokada, karantina, pandemija je prourokovala neočekivani, indirektan pozitivan uticaj na životnu sredinu, pružajući biosferi šansu za oporavak.

Eskperti iz različitih oblasti predviđaju da bi emisija štetnih gasova mogla da opadne do nivoa koji nije ostvaren još od II svetskog rata (Biočanin et al., 2020). Razlog tome jeste socijalno distanciranje $i$ zabrane kretanja kao deo neophodnih mera većine zemalja radi obuzdavanja širenja pandemije. Zabrana kretanja ljudi dovela je do smanjene upotrebe avio-saobraćaja i motornih vozila, kako javnog tako i privatnog prevoza, a to je rezultiralo smanjenjem štetnih čestica u vazduhu. Fabrička postrojenja su stopirala svoje pogone što je dovelo do drastičnog smanjenja emisije ugljen-dioksida u atmosferi. Usled zabrane putovanja, veliki broj plaža je mnogo čistiji jer se broj turista na njima drastično smanjio tokom prethodne godine. Kina, država u kojoj se pojavio virus SARS-CoV-2, prvi put je registrovala smanjeno zagađenje vazduha od nastanka pandemije nakon dugo vremena.

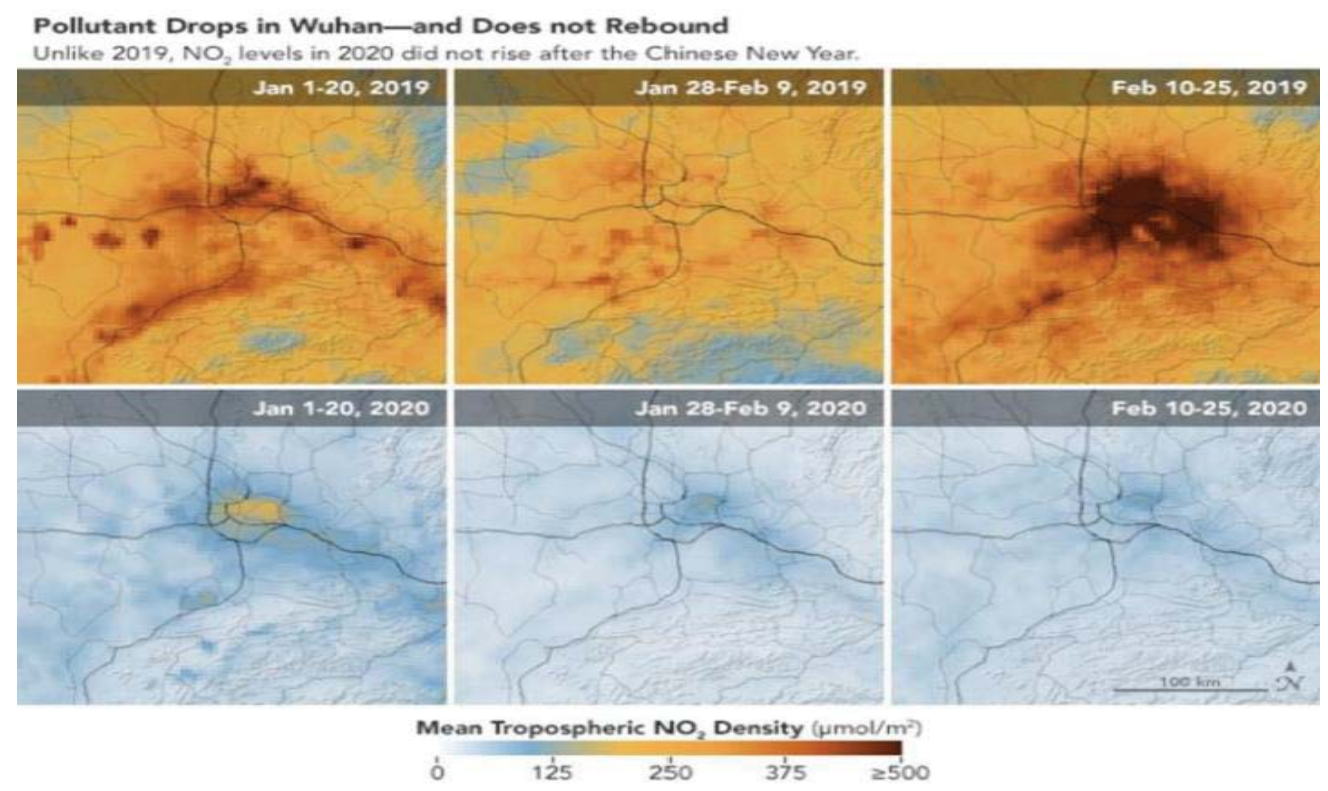

Slika 3 - Zagađenje vazduha u Vuhanu pre i tokom perioda pandemije Figure 3 - Air pollution in Wuhan before and during the pandemic period Izvor / Source: Kottasova, 2021.

Marshall Burke, naučnik i profesor na univerzitetu Stanford, tokom svog istraživanja otkrio je da efekat koji virus korona ima na životnu sredinu, potencijalno može da spasi više života nego što će uzeti. Proračuni profesora Burkea otkrili su da smanjenje emisije štetnih čestica PM2.5 može da spase 77.000 života kineskih stanovnika (Kottasova, 2021).

Dobar primer promena kod turističkih resursa pod uticajem pandemije COVID-19 je prelepa i čarobna Venecija - „La Serenissima“, lepotica Jadrana, gde je prema procenama do pojave pandemije u njenim čarima uživalo preko 20 miliona ljudi godišnje (Sorak Ranković, 2021). Usled pandemije COVID-19 kanali i ulice ovog grada na obali Jadranskog mora su puste. Impozantan broj turista svakodnevno tokom čitave godine, preopterećene gondole i kanali, deo su sećanja na dane kada je turizam bio u punom sjaju i beležio eksponencijalni rast broja posetilaca i priho- da. Voda venecijanskih kanala je sada toliko čista da su vidljive ribice koje u njoj plivaju, a pojavili su se i labudovi. Slabiji saobraćaj i odsustvo turista doprineli su čistijem izgledu vode i poboljšanom kvalitetu vazduha.

Pored brojnih i značajnih gore navedenih pozitivnih efekata pandemije na zaštitu životne sredine, postoje i negativni indirektni faktori. Neki gradovi u SAD, obustavili su programe reciklaže zbog straha nadležnih organa od širenja virusa među zaposlenima. Do početka 2020. godine, tačnije do pojave COVID-19, brojne kompanije vodile su i propagirale politiku podsticanja potrošača da nose svoje torbe prilikom odlaska u kupovinu i smanje upotrebu kesa za jednokratnu upotrebu. Ipak, poslednjih meseci situacija je potpuno drugačija; primećeno je intenzivno vraćanje u upotrebu kesa za jednokratnu upotrebu. Međutim, naručivanje robe putem online plat- 
formi, kao i kada je reč o hrani, uslovilo je drastično povećanje otpada. Prema Munitlak Ivanović i Vujović (2021) stubovi koji čine koncept održivog razvoja su pretrpeli neku vrstu promene usled delovanja pandemije, a time je pitanje održivog razvoja i životne sredine ponovo dobilo na značaju.

3. STUDIJA SLUČAJA - RAZVOJ EKOTURIZMA SRBIJE NA PRIMERU DONJEG PODUNAVLJA / CASE STUDY - DEVELOPMENT OF SERBIAN ECOTURISM ON THE EXAMPLE OF THE LOWER DANUBE REGION

Turistička industrija i globalno turističko tržište nalaze se pod velikim pritiskom i trpe najveće posledice nastale pod uticajem pandemije COVID-19. Rezultati brojnih istraživanja kako na globalnom tako i na nivou naše zemlje, pokazuju da su u 2020. godini odmori u prirodi, naročito u ruralnim i manjim naseljima bili više zastupljeni nego prethodnih godina i u velikoj meri privlače sve veći broj turista. Jedan od primera u Republici Srbiji koji je prethodne 2020. godine zabeležio rast broja posetilaca jeste prostor destinacije Donjeg Podunavlja.

Destinacija Donje Podunavlje prema Strategiji razvoja turizma Republike Srbije 2016-2025 obuhvata prostor duž leve obale Dunava, na njegovom toku između Velikog Gradišta, pa do ušća Timoka. U administrativnom smislu obuhvata pet opština istočne Srbije: Veliko Gradište, Golubac, Majdanpek, Kladovo i Negotin. Ova destinacija ima veliki broj prirodnih i antropogenih resursa, a mogućnost za razvoj ekoturizma u Donjem Podunavlju počiva na očuvanim prirodnim ekosistemima, geonasleđu, arheološkim nalazištima i istorijskim spomenicima, zdravoj vodi i hrani, gostoljubivosti lokalnog stanovništva (Lukić, Petrović, 2019). U okviru ove destinacije domininantan je zaštićeni prostor prvog stepena, prostor Nacionalnog parka „Đerdap“. Nacionalni park „Đerdap“ osnovan je 1974. godine i nalazi se $u$ istočnom delu Srbije, na samoj granici naše zemlje sa Rumunijom, prostirući se na $63.786,48$ ha i najveći je nacionalni park u Srbiji. Kao znak raspoznavanja ovog zaštićenog prostora izdvaja se grandiozna Đerdapska klisura, koja je najduža i najveća klisura probojnica u Evropi. Đerdapsku klisuru čine tri kotline i četiri manje klisure koje se naizmenično smenjuju u dužini od gotovo $100 \mathrm{~km}$. Bogatstvo i raznovrsnost flore i faune, preko 1100 biljnih i 150 životinjskih vrsta, kao i veliki broj kulturnoistorijskih spomenika, od perioda praistorije do danas, samo su deo bogate riznice kojom ovaj zaštićeni prostor raspolaže. Zahvaljujući bogatstvu prirodnih potencijala kojima raspolaže prostor Nacionalnog parka „Đerdap“ posetiocima su na raspolaganju različite aktivnosti u prirodi: biciklizam, planinarenje, speleologija, lov i ribolov, pešačke ture, aktivnosti na vodi, posmatranje ptica i druge, a koje su prepoznate kao atraktivne aktivnosti ekoturizma. Zahvaljujući bogatstvu geonasleđa od jula 2020. godine prostor Nacionalnog parka „Đerdap“ proglašen je prvim geoparkom na našem prostoru u okviru projekta UNESCO Global Geoparks, a od decembra 2020. godine uvršten je i na UNESCO listu Ramsarskih područja.

Duž Đerdapske klisure veliki je broj atraktivnih lokaliteta - vidikovaca koji doprinose dodatnom utisku u toku boravka na ovom značajnom ekopodručju. Za ljubitelje posmatranja ptica, oaza ptica u Maloj Vrbici predstavlja idealno mesto za razvoj sve popularnijeg „birdwatching“ turizma. Oaza ispunjava stroge zahteve zasnovane na prisustvu ugroženih vrsta i njihove brojnosti i na osnovu njihove primene ubraja se u grupu od 35 identifikovanih „Important Bird Areas" (IBA) u Srbiji, a upisana je i na UNESCO Ramsarsku listu zaštićenih vlažnih staništa. Blederijski vodopad, izuzetan i redak prirodni resurs ovog dela Srbije, zajedno sa brojnim pećinama u svom okruženju, idealno je mesto za ljubitelje avanturističkog turizma.

Atraktivna je evropska biciklistička ruta Euro Velo 6 "Iron Gates" ruta koja prolazi kroz Srbiju trasom duž Dunava kroz Donji Milanovac, kao biciklistički koridor koji spaja Atlantski okean i Crno more. Važan deo ove rute prolazi magistralnim putem M25-1, duž Đerdapske klisure, duž koje je osmišljena adekvatna turistička signalizacija, kao i odmorišta specijalizovana za ovu vrstu ekoaktivnosti.

Evropska pešačka asocijacija osmislila je projekat Evropskih pešačkih ruta. To je mrežu dugih pešačkih staza koje prelaze preko teritorije skoro cele Evrope. Putevi vode isključivo kroz prirodu i podrazumevaju blizinu kulturno-istorijskih spomenika, planina, banja, jezera itd. i njima se kreću planinari, turisti i svi oni koji žele da pređu određenu distancu, uživaju u prirodi i upoznaju specifičnosti određenog podneblja. Do sada je definisano 12 evropskih pešačkih puteva i njihova ukupna dužina prelazi $55000 \mathrm{~km}$. Kroz Srbiju prolaze dva evropska pešačka puta - E4 i E7 u dužini od $3500 \mathrm{~km}$. Deo rute E4 prolazi upravo kroz prostor destinacije Donjeg Podunavlja i predstavlja atraktivan resurs u okviru ekoturizma ovog prostora imajući u vidu veliki broj stranih posetilaca koji preferiraju ovu vrstu aktivnosti.

Svetska zdravstvena kriza 2020. godine uslovila je intenzivnu upotrebu informacionih tehnologija u svim granama privrede uključujući i sektor turizma i doprinela da digitalizacija postane glavni preduslov razvoja destinacija u post-COVID vremenu. Jedna od prvih destinacija koja je prepoznala potrebu digitalizacije i implementirala je u svoje poslovanje jeste 
turistička organizacija Kladova, predstavljajući na originalan, jedinstven način svoje turističko blago u vidu „free E-book-a." On-line publikacija „Tajne Kladova“ na zanimljiv i ilustrovan način prezentuje potencijale destinacije Kladovo i prostora Donjeg Podunavlja.

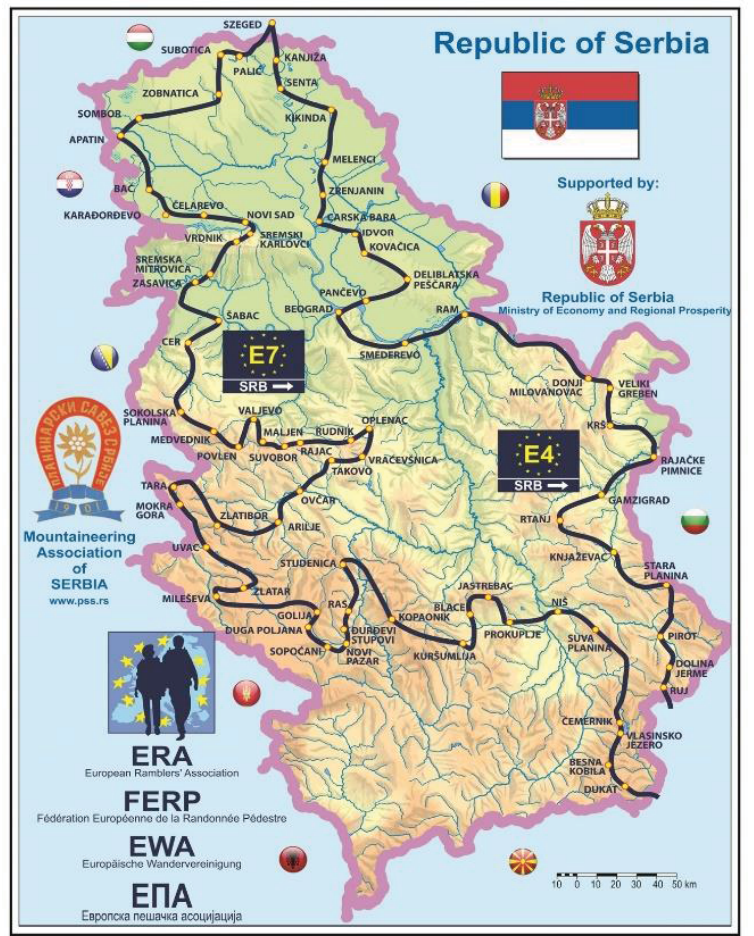

Slika 4 - Evropski pešački putevi u Srbiji

Figure 4 - European pedestrian roads in Serbia Izvor / Sorce: http://pkbalkan.org/

Imajući u vidu resursnu osnovu ovog dela Srbije, kao i niz međunarodnih projekata saradnje i podrške, uz sve veću tražnju na turističkom tržištu ekoturizam predstavlja veliku razvojnu šansu turizma na ovim prostorima, a to je jasno dato u okviru pregleda turističkih proizvoda prema destinacijama definisanim Strategijom razvoja turizma Republike Srbije 20162025 (Jovanović, 2017). Prepoznati su pozitivni efekti ekoturizma na okruženje sa ekološkog aspekta kako kroz formu zaštite prirodnih dobara, tako i kroz ograničavanje mogućnosti valorizacije pojedinih vrsta turizma koje imaju negativan uticaj $\mathrm{i}$ dovode do prekomernog broja turista (overtourism). Takođe, $\mathrm{u}$ funkciji razvoja ekoturizma neophodno je analizirati i ekonomske efekte kroz mogućnost povećanja prihoda učesnika u organizaciji i realizaciji aktivnosti: domaćinstava, preduzetnika i lokalnih samouprava, a indirektno i nacionalnog budžeta. Istovremeno, društveni efekat je značajan sa aspekta uključivanja lokalnog stanovništva u organizaciju i realizaciju turističkih aktivnosti, uz očuvanje kulture, tradicije i identiteta lokalnih zajednica. Edukacija lokalnog stanovništva o principima i značaju održivog razvoja turizma, u formi
Budući turisti preko pomenute platforme mogu da se upoznaju sa samom turističkom destinacijom, turističkom infrastrukturom i suprastrukturom, prirodnim i kulturnim blagom

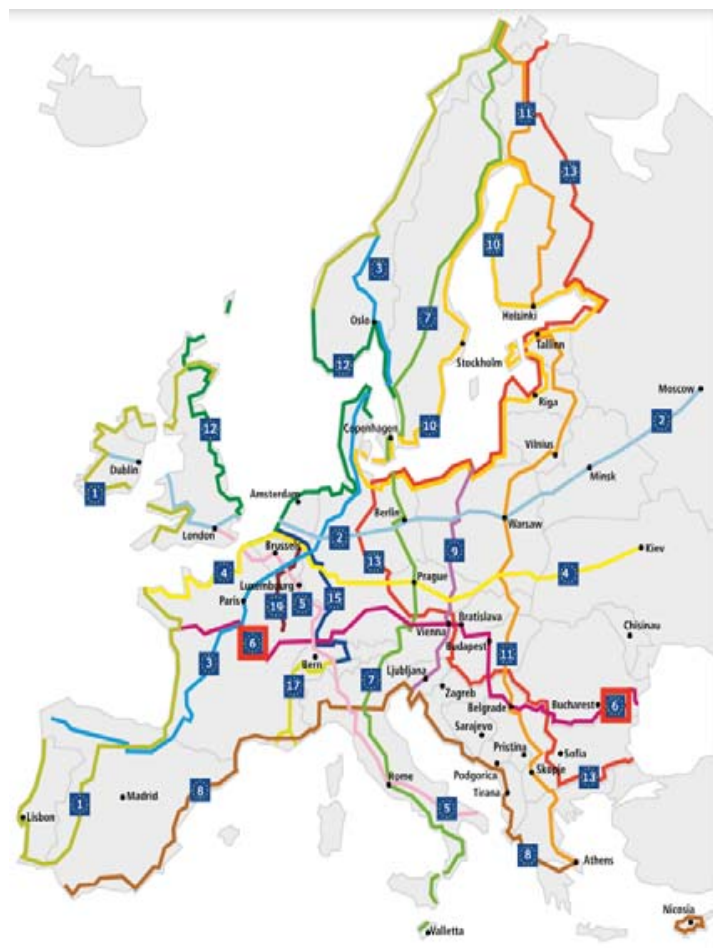

Slika 5 - Biciklističke rute kroz Srbiju Figure 5 - Bicycle routes through Serbia Izvor / Source: https://cyclingeurope.org/

ekoturizma, ali i širenje svesti kod stanovništva doprineće dodatnom rastu tražnje za ovom specifičnom vrstom turizma u Srbiji. Zahvaljujući implementaciji principa održivog turizma moguć je rast tražnje za ekoturizmom u Srbiji, kao i doprinos razvoju sa ekonomskog, društvenog i ekološkog aspekta lokalnih zajednica na ovom prostoru. Dakle, razvoj ekoturizma na prostoru Donjeg Podunavlja trebalo bi da donese značajan napredak turizmu u Srbiji, otvorena vrata za sve ljude željne mira, čiste prirode, kao i doprinos rastu nacionalnog budžeta (Unković, Zečević, 2016).

Uzevši u obzir činjenice koje navode Wearing i Neil (2009) definišući specifičnosti ekoturiste tj. da su to osobe starosti $35-54$ godine, da je $82 \%$ njih visoko obrazovano, da su informatički pismeni, kao i da su izazovi koji njih privlače ovoj specifičnoj vrsti turizma usmereni na uživanje u predelu/prirodi, pešačenje, posmatranje životinja, kao i nova iskustva, uz činjenicu da je kod ekoturizma karakteristično i to da su grupe turista manjeg obima, do 25 osoba, više je nego sigurno da atraktivan turistički prostor Donjeg Podunavlja, sa velikim brojem autentičnih prirodnih 
lokaliteta ima velike potencijale na turističkom tržištu, kada je u pitanju razvoj ekoturizma Srbije.

\section{ZAKLJUČAK / CONCLUSION}

Svaka kriza zahteva adekvatan i pravovremen odgovor u cilju uspešnog prevazilaženja svih nedaća koje sa sobom nosi. Pandemija COVID-19, ukazala je na nespremnost velikog broja država da se suoče sa novonastalom situacijom i efikasno i uspešno prevaziđu rapidno nadolazeće probleme. Globalna zdravstvena kriza još nije završena i ne zna se kada će, a prouzrokovane posledice se još ne mogu registrovati, ali je vidljivo da je industrija turizma najviše njome pogođena.

Prirodna sredina je pod uticajem velikog broja antropogenih faktora koji deluju na različite načine i prouzrokuju niz negativnih efekata na održivi razvoj planete zemlje. Veliki porast broja stanovnika i prenaseljenost, sagorevanje fosilnih goriva, krčenje šuma, istrebljenje brojnih endemskih vrsta, kao i intenzivan razvoj turizma, vezuju se za negativan uticaj čoveka na biodiverzitet i veoma je teško reći koji su to benefiti masovnog turizma na prirodno okruženje. Upravo u tome se ogleda značaj razvoja ekoturizma, naročito kada je reč o upravljanju i zaštiti prirodnih resursa. Od posebne važnosti su aktivnosti minimiziranja negativnog uticaja čoveka na prirodno okruženje, a jedan od načina pomenutog ostvarenja svakako je podizanje ekološke svesti stanovništva i edukacija turista. Ekoturizam ima jedinstvenu ulogu u edukaciji putnika o vrednosti zdrave okoline i biološke raznolikosti. Međutim, pravilno planiranje i upravljanje su presudni za njegov razvoj.

Ekoturizam je rastuće tržište unutar turističke industrije sa potencijalom da bude važno sredstvo održivog razvoja. Operativni mehanizam ekoturizma je jedinstven, jer njegov cilj nije samo postizanje poslovnog profita, već i održivi rast i očuvanje životne sredine. Ekoturizam, kao specifična tržišna niša i deo koncepta održivog razvoja, predstavlja veliku i idelanu priliku za razvoj turizma Srbije. lako Srbija obiluje resursima, ekoturizam je u povoju, a njegova zastupljenost $u$ turističkim tokovima naše zemlje je veoma niska. Neodovoljno postojanje eko-turističkih proizvoda i usluga, kao i manjak motivisanosti turističkih subjekata u kreiranju istog, samo su deo razloga niskog učešća i razvoja pomenutog vida turizma u Republici Srbiji.

Dakle, može se istaći da je pandemija novog virusa, jedna sistemska kriza koja je dala veliko upozorenje čovečanstvu da nebriga i nemarnost ugrožavanja životne sredine mogu da dovedu u pitanje opstanak čitavog ljudskog roda. Jedan od malobrojnih benefita pandemije, možda čak i jedini, jeste oporavak "zatrovane“ prirode posle dugo vremena. Za dalji oporavak, ali rast i razvoj industrije turizma neophodni su edukacija i investicije u održive oblike turizma, kao što je npr. ekoturizam.

\section{LITERATURA / REFERENCES}

[1] Biočanin, R., Ketin, S., Badić, M., Demović, Z., Čolaković, M. (2020). Korporativno-društvena odgovornost u razvoju eko-turizma u kontekstu uzroka i posledica pandemije virusa COVID-19, Zbornik radova, Centar za nauku i kulturu NAUKAKOM, Novi Pazar

[2] Bradić-Martinović, A., Miletić, B. (2018). Odgovorni i održivi razvoj turizma u Srbiji - Ekoturistički park Palić, Ecologica, 25(92), 777-781.

[3] Dražić, G. (2018). Održivi turizam, Univerzitet Singidunum, Beograd-

[4] Đurović, S., Perović, A., Šiljak, V., Antonijević, S., Veselinović, J., Baćevac, S. (2020). Održivost razvoja sportskog turizma kao privredne grane: uticaj COVID-19, Ecologica, 27(100), 699-706.

[5] https://cyclingeurope.org, pristupljeno 04.04.2021.

[6] https://ecotourism.org/what-is-ecotourism/, pristupljeno 27.02.2021.

[7] http://www.fao.org/3/w7714e/w7714e06.htm\#3. \%20ecotourism, pristupljeno 27.02.2021.

[8] https://www.marketwatch.com/pressrelease/global-ecotourism-market-size-study-bytype-alternative-tourism-responsible-tourismsustainable-tourism-community-tourism-byapplication-below-20-years-20-50-years-above50-years-and-regional-forecasts-2019-20262021-02-25?tesla=y, pristupljeno 02.03.2021.

[9] http://pkbalkan.org, pristupljeno 04.04.2021.

[10] https://www.statista.com/statistics/1221034/ecot ourism-market-size-global/ pristupljeno 02.05.2021.

[11] https://tajneputnika.com/2020/11/02/digitalizacija -turisticke-ponude-kladova/, pristupljeno 01.03.2021.

[12] International Tourism Highlights, 2020 Edition, UNWTO, Madrid, 2021, preuzeto 01.03.2021. https://www.eunwto.org/doi/epdf/10.18111/9789284422456

[13] IUCN Programme (2017-2020), World Conservation Congress, 6th, Hawaii, US, 1-10 September 2016,

https://portals.iucn.org/library/sites/library/files/do cuments/WCC-6th-001.pdf,preuzeto 01.03.2021.

[14] Janković, M., Ivannikov, N., Jovanović, L., Gajdobranski, A. (2020). Doprinos zelene ekonomije razvoju ekoturizma i organskoj proizvodnji, Ecologica, 27(98), 217-223. 
[15] Janković, M., Jović Bogdanović, A., Gajdobranski A. (2021). Uticaj pandemije na ekonomski razvoj, Ecologica, 28(101), 112-117.

[16] Jovanović, V. (2017). Turizam i prostor, Univerzitet Singidunum, Beograd.

[17] Kottasova, I. (2021). China's coronavirus lockdown curbs deadly pollution, likely saving the lives of tens of thousands, says researcher, pristupljeno 23.02.2021.

https://edition.cnn.com/2020/03/17/health/chinaair-pollution-coronavirus-deaths-intl/index.html

[18] Lindberg, K. (1991), Policies for Maximizing Nature Tourism's Ecological and Economic Benefits. Washington, DC: World Resources Institute

[19] Lukić, D., Petrović, M. (2019). Uloga objekata geonasleđa u turizmu Podunavlja Srbije, Geografski institut "Jovan Cvijić", Beograd

[20] Marković, J. (2019). Tematski turizam, Prirodnomatematički fakultet, Univerzitet u Novom Sadu, Novi Sad

[21] Munitlak Ivanović, O., Vujić, M. (2021). Posledice delovanja COVID 19 na ekonomski sektor i životnu sredinu, Ecologica, 28(101), 118-124.
[22] Sorak Ranković, T. (2021). Ljudi u izolaciji, Venecija u punom sjaju,

https://www.nationalgeographic.rs/vesti/14944ljudi-u-izolaciji-venecija-u-punom-sjaju-dokkorona-drzi-italiju-pod-kljucem-voda-u-kanalimaizgleda-cistije-nego-proteklih-decenija.html, pristupljeno 23.02.2021.

[23] Strategija razvoja turizma Republike Srbije 2016 $-2025$ https://mtt.gov.rs/download/3/STRATEGIJA\%20 RAZVOJA\%20TURIZMA\%20RS\%20\%2020162025.pdf

[24] Tourism`s Potentials as a Sustainable Development Strategy. (2005). UNWTO, Madrid

[25] Unković, S., Zečević, B. (2016). Ekonomika turizma, Ekonomski fakultet, Beograd

[26] Wearing, S., Neil, J. (2009). Ecotourism: Impacts, Potentials and Possibilities, Butterworth Heinemann, Oxford

[27] Wood Epler, M. (2002). Ekoturizam: principi, postupci i politike za održivost, CenORT, Beograd. 